\title{
REGIONAL AND TRADITIONAL PRODUCTS - SOME COMMENTS FROM THE SEGMENTATION, PROMOTION AND LOCAL DEVELOPMENT PERSPECTIVES
}

\author{
Rafał MAZUR \\ West Pomeranian University of Technology in Szczecin, Faculty of Economics; rmazur@zut.edu.pl, \\ ORCID: 0000-0001-8828-5925
}

\begin{abstract}
The perception of regional (traditional) products may vary - some consider them an element of consumption, others see them as a part of culture and of a tourist experience of a certain place. By buying regional products, tourists not only satisfy their needs, but also interact with local culture and support the development of a given community through stimulating demand. Tourists' tendency to consume local products is connected with several spheres: the visitors' motivations, their personality traits, and the sociodemographic features. The following article has two objectives: 1) to identify what proportion of guests visiting seaside tourist destinations is interested in local products; 2) to determine the characteristics of people who are not interested in local products, and to propose a modified market segmentation and communication concept.

The results of the survey show that almost $68 \%$ of tourists are interested in local products. What is more, nearly $65 \%$ of respondents said that this interest also translates into the desire to visit the region. Some of the uninterested respondents (32.3\%) are young people, aged 19-35in order to reach them with the offer of local products, a modified market segmentation should be made, and a promotion should be planned that will attract their attention. The concept of cross-promotion was proposed here, which means providing information about local products on such occasions as concerts or sporting events. It is important that this could be done both via the Internet and through printed materials available in tourist accommodation facilities.
\end{abstract}

Keywords: local development, traditional products, promotion, lifestyle, tourists.

\section{Introduction}

Observing changes in developed markets, one can notice an increase in wealth and awareness of societies, and thus, changes in lifestyle, changes in working conditions, as well as changes in ways of and motivations for spending free time. All this impacts the development of tourism, which has become a part of politics on all levels (international, national, regional) on the one hand, and on the other hand - a way of individually searching for a more valuable 
life (Bucher, 2015). As a result, the consumers' awareness concerning healthy lifestyle is increasing, and thus they are more likely to, for instance, pay more for better-quality food and to check the health benefits and taste of products. Therefore, it is worth paying attention to regional and traditional goods, which are often unique and at the same time are a specific distinguishing feature of the regions.

Tourists are usually interested not only in the history of the place, but also in issues related to products that are made locally, in accordance with tradition passed down from generation to generation. Poland is undeniably a country with an interesting culture, having excellent conditions for the manufacturing of high-quality food products with unique taste parameters. Moreover, rural transformations and biodiversity are the basis for the development of a traditional food market. Therefore, consumers more and more often decide to buy regional products in order to learn about the flavours of a given region, among others. Traditional and regional products are not only unique tastes, but also high quality and strictly defined recipes, which is why it is an interesting proposition for people who care about healthy eating (Grębowiec, 2017). Local and regional products are thus worth cultivating and promoting. This is also emphasised by M. Woźniczko (2015), who writes that Poland as a member of the European Union, in which around 39\% of inhabitants live in rural areas and over $15 \%$ are employed in agriculture, has a vested interest in participating in the European food protection and promotion system. Our country's cultural and historical wealth as well as non-industrial methods of agricultural production may result in a greater presence of regional and traditional products in Poland. Not without significance are regional and traditional products in the so-called peripheral areas (Malkowski, 2017), which are less developed and their promotion could be an element attracting tourists and giving a chance for sustainable development. Looking for stimulants of local development on the one hand, and good quality food on the other, which will meet the expectations of tourists, it is impossible to ignore traditional and regional products.

Taking into account the above considerations, the first objective of this article is to determine what percentage of visitors to seaside tourist destinations are interested in local products and what percentage are not. The second objective is to determine the features of people who are not interested in local products, and to propose: 1) a modified segmentation of the market, 2) a communication concept. The research method used in the paper is the survey questionnaire, which was conducted in July 2019 in coastal towns of the Pomeranian and West Pomeranian voivodeships on a sample of 223 respondents.

Despite there being numerous publications on regional tourism and local products, it seems that this work complements the current considerations by drawing attention to the overly simplified use of market segmentation, as well as the lack of proper communication with potential tourists. Certain practical implications can also be pointed out, as the results of our study can potentially be used by local governments and producer organisations to create a new promotion policy. 


\section{Literature review}

Tourism can be perceived as a form of economic activity which creates employment and revenue, but it can also be considered from a tourist's point of view - the richness of interactions between the visitors and the local destinations makes the tourism indu stry unique. Certainly by buying local products, the visitors to a given place not only fulfil their basic needs, but also interact with the local culture and through stimulating demand they support the development of a given community. It is described by Madaleno, Eusébio, and Varum (2018), who emphasise that tourism influences local destinations in various ways, and that a synergy can be observed between tourism and local products. The perception of regional (traditional) products may vary - some consider them an element of consumption, others see them as an indispensable part of culture and of the tourist experience of a place (Fields, 2002).

The tendency of tourists to consume local products - as described by Fields (2002), and also Kim and Eves (2012) - is connected with three spheres: motivation of the visitors, their personality traits, and the sociodemographic features. They distinguished five special motivational factors which encourage to consume local products, namely: caring for one's health, cultural competency, willingness to experience, sensory attractiveness of products, and experiencing interpersonal relations. Therefore, the consumption of traditional products can be considered a truly cultural experience, connected with experiencing something new. It can also be connected with the desire to spend time with family or friends. Finally, sensory experience (smell, touch, taste, image) connected with local food products can play a key role in appreciating food and influence its choice, since tasting local dishes while on holidays is simply a pleasant sensual experience (Aprile et al., 2016). Thus, as mentioned, personality traits are important, such as the desire to learn something new, as well as whether, for example, a given tourist travels alone or with their family. Moreover, Suhartanto et al. (2018) indicate that an important factor influencing the tourists' choices is the perception of product quality.

Tourists are specific consumers, as they arrive at a given place for a short period of time and expect their needs to be met in a special way, i.e. one which will provide them with an unforgettable experience. This is an opportunity for local business owners, who can use the resources of a given destination and meet the expectations of the visitors while developing their business (Marrocu, Paci, 2011). In order to make this possible, however, they need to know these expectations and also communicate efficiently with the potential visitors (Hernik, Smalec, 2013), as the formed knowledge of tourists can be the key factor activating their consumption. For instance, wine consumers will seek particular grape varieties, apple consumers will be able to pick those with specific flavours, honey consumers will look for the healthiest kind, while ham consumers will be willing to pay more if they know the method of preparation. It is therefore important what kind of information is available prior to arriving at a given destination and also during the stay (Wu et al., 2015; Barlagne et al., 2015). The actions 
promoting local products should not only be the responsibility of the manufacturers, who often have neither the knowledge nor the means to promote their product successfully. Cooperation is needed between the producers and the local government, which should involve the formation of sustainable development policy (McLoughlin, Hanrahan, 2019).

Marketing management plays an important role here, that is, one that targets the needs of the recipients. What is interesting, these needs have been recently changing when it comes to holidaying at a countryside or in small towns offering regional specialties (Barros et al., 2011). It turns out that the simpler conditions the tourists live in, the better. And so what used to be commonplace and simple has now become significant, and new recipients of local tourism and its products appeared. This does not mean that an offer for such tourists should be cheap, because they expect simplicity with a little bit of luxury, as M. Sikorska (2018) states. This is connected with creating entire segments of new recipients of tourist services, whose expectations go way beyond a comfortable room and a beach - they want attractions which will enrich their stay with something special. It is thus not enough to know whether a tourist is male or female, or that they are of a certain age; it is important to be aware whether they are adventure seekers, or slow food consumers. In order to effectively reach such consumers with marketing activities, especially promotion, and to create competitiveness of a tourist destination, a good strategy as well as a public-private partnership are needed (Jung, Ineson, and Miller, 2014). Equally important, however, is the understanding of consumer motivations, which of course are related to education, age and gender, social position or stage in a family life cycle, but also to the adopted lifestyle (Koziol, 2012).

\section{Regional and traditional products - characteristics and protection}

Two terms are important for regional and traditional products: the protection system and the quality assurance system. Both were included in the so called Protected Designation of Origin (PDO), Protected Geographical Indication (PGI), and Traditional Speciality Guaranteed (TSG). The system has been operating since 1992, when it was introduced by Council Regulation (EEC) No 2081/92 of 14 July 1992 on the protection of geographical indications and designations of origin for agricultural products and foodstuffs. Currently, the system of protection and promotion of regional and traditional products in the European Union operates on the basis of Regulation (EU) No 1151/2012 of the European Parliament and of the Council of 21 November 2012 on quality schemes for agricultural products and foodstuffs. This regulation combines the solutions hitherto included in Council Regulation (EC) No 509/2006 of 20 March 2006 on agricultural products and foodstuffs as traditional specialities guaranteed and in Council Regulation (EC) No 510/2006 of 20 March 2006 on the protection of geographical indications and designations of origin for agricultural products and foodstuffs. More specific issues are also regulated by Commission Delegated Regulation (EU) No 664/2014 of 18 October 2013 supplementing Regulation (EU) No 1151/2012 of the European Parliament and of the Council with regard to the establishment of Union symbols 
regarding protected designations of origin, protected geographical indications and traditional specialities guaranteed, and as regards certain rules on the origin of feed and raw materials, certain procedural provisions, and certain additional transitional provisions (Gulbicka, 2014). These documents speak of agri-food products with characteristic features resulting from the specificity of the region in which the product is produced, or from a traditional method of production in accordance with the culinary heritage, and this is how regional and traditional products should be understood.

The system of protection of regional and traditional products in the European Union is modeled on the French system. It involves the certification and labelling of regional and traditional agri-food products, manufactured according to the recipes handed down from generation to generation. Manufacturers of such products, i.e. protected products, have the right to mark them with appropriate signs that testify to the qualities and uniqueness of labelled products under the Common Agricultural Policy (Gulbicka, 2014).

The purpose of Regulation No 1151/2012 is to support producers of agricultural products and foodstuffs in informing buyers and consumers about the characteristics of products and foodstuffs and related agricultural production, in order to ensure:

a) fair competition - for farmers and producers of agricultural products and foodstuffs having added value characteristics and properties,

b) consumer access to reliable information on these products,

c) compliance with intellectual property rights,

d) integrity of the internal market.

The measures set out in the regulation are intended to support agri-processing activities and agricultural systems related to high-quality products in order to contribute to achieving the objectives of rural development policy. (Article 1 of the Regulation of the European Parliament).

In Poland, the unit responsible for operating the registration system for products with certain geographical origin and specific, traditional quality, as defined by EU regulations, is the Ministry of Agriculture and Rural Development. Pursuant to the Act on the registration and protection of names and designations of agricultural products and foodstuffs as well as on traditional products (Journal Of Laws of 2017, item 1168), the Ministry of Agriculture and Rural Development is responsible for receiving, evaluating and forwarding applications for registration of designations of origin, geographical indications and traditional specialities guaranteed to the European Commission. This is done in accordance with the provisions of the Act on the registration and protection of names and designations of agricultural products and foodstuffs, as well as on traditional products, which provides, inter alia, the principles and procedure for assessing applications for registration of designations of origin, geographical indications and traditional specialities guaranteed, and orders the creation of a list of traditional products. The list includes products whose quality or unique features and properties result from the use of traditional production methods, which are part of the cultural heritage of the region 
in which they are produced, and that constitute part of the identity of the local community. Production methods used for at least 25 years are considered traditional. The list of traditional products is intended to disseminate information on products produced by traditional, historically well-established methods (Website of the Ministry of Agriculture and Rural Development).

Traditional products can therefore be, among others, local products that have been entered on the List of traditional products (Act of 17 December 2004 on the registration and protection of names and designations of agricultural products and foodstuffs as well as on traditional products - Journal of Laws of 2005 No. 10, item 68)

Listing a product usually means the first stage of applying for product registration in the EU protection system. Under this system, agricultural products, foodstuffs or spirit drinks may obtain one of the designations awarded by the European Commission. These include: Protected Designation of Origin (PDO), Protected Geographical Indication (PGI), or Traditional Speciality Guaranteed (TSG).

The number of traditional products in our country is increasing and currently 1,918 products are entered into the register of traditional products kept by the Ministry of Agriculture - while in 2008 there were only 521 traditional products in that register (Tab.1). This is a positive symptom of recognising the potential of traditional products.

Table 1.

The number of traditional products in individual voivodeships in Poland

\begin{tabular}{|l|c|c|}
\hline Voivodeship & $\mathbf{2 0 0 8}$ & $\mathbf{2 0 1 9}$ \\
\hline Lower Silesian & 14 & 52 \\
\hline Kuyavian-Pomeranian & 15 & 214 \\
\hline Lublin & 43 & 80 \\
\hline Lubusz & 6 & 142 \\
\hline Lódź & 21 & 220 \\
\hline Lesser Poland & 26 & 147 \\
\hline Masovian & 10 & 62 \\
\hline Opole & 43 & 236 \\
\hline Podkarpackie & 66 & 71 \\
\hline Podlaskie & 36 & 179 \\
\hline Pomeranian & 75 & 145 \\
\hline Silesian & 81 & 94 \\
\hline Swiętokrzyskie & 17 & 42 \\
\hline Warmian-Masurian & 17 & 93 \\
\hline Greater Poland & 45 & $\mathbf{1 0 1 8}$ \\
\hline West Pomeranian & 6 & $\mathbf{9 2 1}$ \\
\hline TOTAL: & $\mathbf{5 2}$ & \\
\hline
\end{tabular}

Source: The website of the Ministry of Agriculture and Rural Development, https://www.gov.pl/web/ rolnictwo/lista-produktow-tradycyjnych12 (accessed 17 August 2019). 
It must be stated here that still few of the traditional products entered on the ministerial list are protected on the basis of an entry in the Register of Protected Designations of Origin, Protected Geographical Indications, and the Register of Traditional Specialities Guaranteed. Until August 2019, such protection had been granted to manufacturers of 42 products, which in relation to the registered number of 1,918 products gives approx. 2.2\%. Most products are protected in countries such as Italy, France and Spain, Portugal and Greece (Tab. 2).

Table 2.

List of products registered as PDO, PGI, TSG (as of 10 August 2019)

\begin{tabular}{|c|c|c|c|c|}
\hline Country & PDO & PGI & TSG & Total \\
\hline Italy & 167 & 130 & 2 & 299 \\
\hline France & 104 & 144 & 1 & 249 \\
\hline Spain & 102 & 90 & 4 & 196 \\
\hline Portugal & 64 & 74 & 1 & 139 \\
\hline Greece & 76 & 31 & 0 & 107 \\
\hline Germany & 12 & 79 & 0 & 91 \\
\hline United Kingdom & 27 & 41 & 4 & 72 \\
\hline Poland & 9 & 23 & 10 & 42 \\
\hline Czechia & 6 & 23 & 5 & 34 \\
\hline Slovenia & 9 & 13 & 3 & 25 \\
\hline Croatia & 12 & 11 & 0 & 23 \\
\hline Belgium & 3 & 11 & 5 & 19 \\
\hline Slovakia & 2 & 10 & 7 & 19 \\
\hline Austria & 10 & 5 & 3 & 18 \\
\hline The Netherlands & 6 & 5 & 4 & 15 \\
\hline Hungary & 6 & 8 & 1 & 15 \\
\hline Finland & 5 & 2 & 3 & 10 \\
\hline Sweden & 3 & 3 & 2 & 8 \\
\hline Bulgaria & 1 & 2 & 5 & 8 \\
\hline Lithuania & 1 & 5 & 2 & 8 \\
\hline Ireland & 3 & 4 & 0 & 7 \\
\hline Denmark & 0 & 7 & 0 & 7 \\
\hline Latvia & 1 & 2 & 3 & 6 \\
\hline Cyprus & 1 & 4 & 0 & 5 \\
\hline Romania & 1 & 4 & 0 & 5 \\
\hline Luxembourg & 2 & 2 & 0 & 4 \\
\hline Estonia & 0 & 0 & 0 & 0 \\
\hline Malta & 0 & 0 & 0 & 0 \\
\hline Total & 633 & 733 & 65 & 1,431 \\
\hline
\end{tabular}

Source: own study on the basis of DOOR, https://ec.europa.eu/agriculture/quality/door/list.html?locale =pl accessed 17 August 2019 .

As mentioned, the specificity of a regional product relates to the place of manufacture, the original composition or the original method of production. The European Union's policy in the area of local and regional products is aimed at protecting their names, but also at promoting their unique features and methods of production (European Commission website). In many European Union countries, the production, protection and promotion of high-quality food play an important role in the development of local communities. One of the basic ways of implementing the Quality Policy in the EU is precisely distinguishing with signs confirming the high quality of agri-food products from specific regions, as well as those characterised by 
the traditional production method. Owing to the system of protection and promotion of regional and traditional products, the cultural heritage of individual regions is also protected, which largely contributes to their attractiveness (Ministry of Agriculture website). This system also gives consumers confidence that they are buying food of very high quality, which is also characterised by a unique, traditional production method.

As demonstrated in Table 2, in terms of the number of registered products, Poland is 8th in the European Union. While it is true that Poland is a leader among the countries admitted to the EU after 2003, however, countries such as the Czech Republic, Slovenia or Croatia are much smaller in terms of population and area, and in this combination the number of protected food ingredients by the EC in Poland does not look so promising.

\section{Materials and methods}

The study in the form of survey questionnaire was conducted on a purposive sample (tourists only) in July 2019, in the following coastal towns of the Pomeranian and WestPomeranian voivodeships: Dziwnów, Dziwnówek, Łukęcin, Pobierowo, Trzęsacz, Rewal, Ustka, Rowy, and Łeba. It was decided to carry out the research in the coastal area due to the fact that tourists from all over Poland stay at the Polish seaside during the summer holiday season. 223 people participated in the study, including 116 women and 107 men.

The survey questionnaire contained 8 questions and concerned the issue of paying attention to regional food products while travelling, sources of information on regional food products, how willingly respondents would buy regional food products, their interest in regional products, and its possible translation into the desire to visit the region. The respondents were also asked about the taste, quality and impact on health as well as the price availability of regional products.

\section{Results and discussion}

The first question asked to the respondents was whether they paid attention to regional products during their holiday stays. Out of 223 respondents, 151 answered positively, which constitutes $67.7 \%$. This is a fairly large group, but obviously tourists come to a given place for other reasons closely related to leisure, while local and regional products are only complementary to the main tourist destination (Rodríguez et al. 2009; Madaleno et al. 2018). 
People who emphasised that they did pay attention to regional products were asked about sources of information. It turns out that the information about regional food products comes primarily from friends $-30 \%$ of indications, but also from local markets and shops $-26 \%$, from the Internet $-23 \%$, and television $-17.9 \%$. The smallest percentage of respondents mentioned the radio $-3.3 \%$ (Figure 1). Similar results were obtained by N. Kozak and M. Kozak (2008), who, relying on their research, stated that tourists obtain information from various sources, and their type mainly depends on the age of respondents.

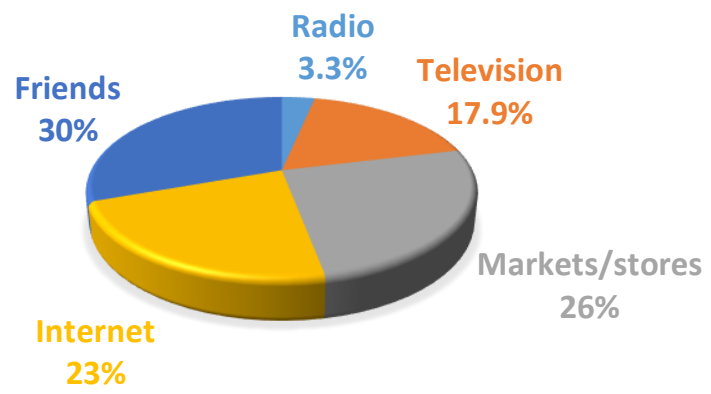

Figure 1. Sources of information on regional and traditional products. Source: own study.

From among respondents interested in local products, $74 \%$ indicated that they willingly bought such products. Nearly $65 \%$ of respondents interested in these products confirmed that their interest in regional products also translated into a desire to visit the region. Of course, the behaviour of tourists - as already mentioned - is conditioned by several important factors, such as previous experience, information available before arrival, information obtained from friends, as well as the image of the destination. This is discussed in the works of Rodríguez (Rodríguez et al., 2018), Dąbrowska (2018), or Madaleno (2018).

The evaluation of regional and local products was important in our study. In order to obtain the respondents' answers as to what they think about local products, a question was created with a 5-point Likert scale. Most respondents interested in regional and traditional products, obviously, say that they are tasty, healthy and of good quality -4 and 5 points $-56.95 \%, 47.02 \%$ and $59.6 \%$ respectively. The assessment of regional products in terms of affordability is slightly different - only $30.47 \%$ of respondents indicated that the products were relatively cheap, while $39.07 \%$ of the surveyed claimed that they were expensive (Figure 2). 


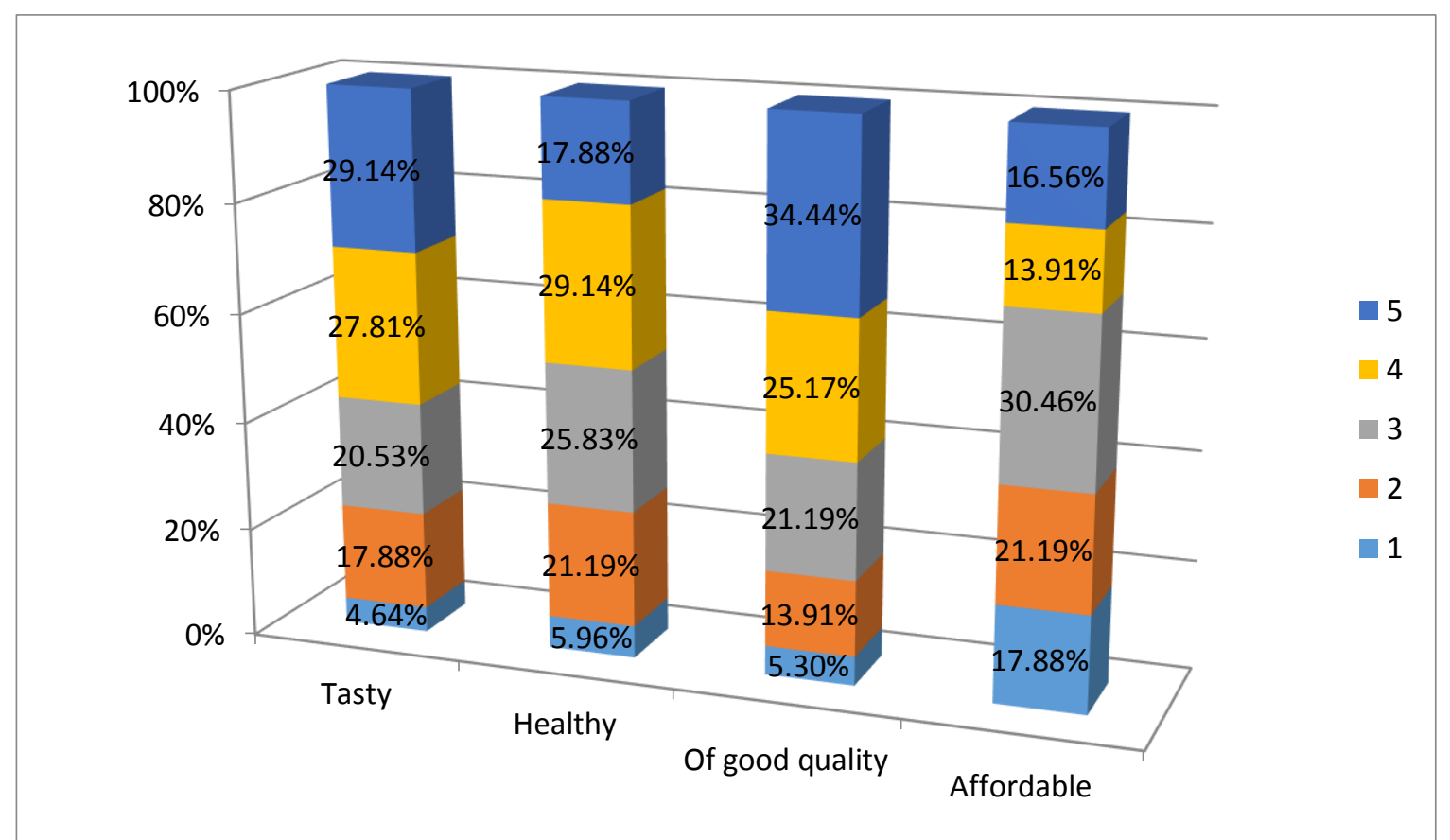

Figure 2. Answers to the question concerning opinions about the features and prices of regional and traditional products. Source: own study.

The answers to this question inspire to take steps as far as promotion is concerned the messages addressed to potential tourists should emphasise the unique taste and quality of local products, but also lexplain their impact on health with more detail. The issue of high prices should not raise any objections if buyers receive adequate explanations as to the method of production and justification for the product's uniqueness (Marrocu, and Paci, 2011).

The second objective of our study is to attempt at determining the characteristics of respondents who are not interested in local products, and to design proposals on how to reach them. In the group of people not interested in local products, there were 38 women and 34 men, so it can be concluded that gender is not a decisive factor. Age, however, is important, as $43 \%$ of respondents were people aged 19-25. In total, people up to the age of 35 constituted $88.9 \%$ of respondents not interested in local products (Figure 3).

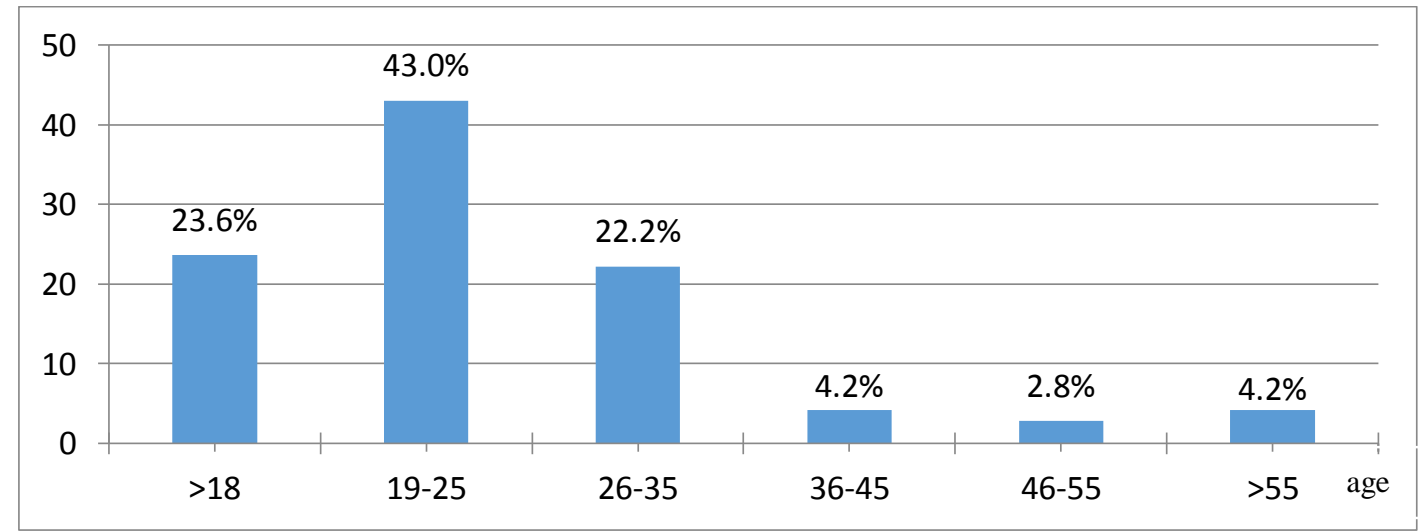

Figure 3. Age analysis of respondents not interested in local products. Source: own study. 
It turns out that among respondents who are not interested in local products, there is no dominant group as far as place of residence is concerned, because $12.5 \%$ of respondents lived in rural areas, $25 \%$ lived in cities up to 20,000 inhabitants, $16.67 \%$ - in cities between 20,000 and 50,000 inhabitants, $26.39 \%$ - in cities with more than 50,000 inhabitants, and $19.44 \%$ declared living in the biggest cities (more than 200,000 inhabitants). It thus seems that the place of residence is not a factor when it comes to choosing local products. In the traditional promotion, it matters if one wants to reach the recipient in their place of residence (Barlagne, 2005; Grębowiec, 2017; Aprile, 2016). However, from the point of view of promoting local products there is no such need, or at least not to such a degree as in the case of mass-produced goods.

It is significant that the lack of interest in local products was declared by people aged 19-35. Age, being the only common feature of this group of respondents, determines the way of communication. Of course, the use of the Internet by young people is widespread, but for effective promotion it is important how friendly the navigation is and whether it is possible to find useful information quickly (Castañeda, 2009). The key issue is: will a young person search for content dedicated to regional products? Rather not. Thus, information about such products must be provided on the occasion of other attractions that may be of interest to young people (cross-promotion). Those can be concerts, cabaret performances, or sporting events. It also seems that the message about the tradition of such products and their health-promoting properties can still be used, but it is rather their unique character that should receive more focus.

Based on our research, we propose a slightly different approach to tourist segmentation it turns out that in the case of interest in local products, gender and place of residence do not matter, while age is significant. Therefore, a modified segmentation should be based mainly on the age criterion, and then on the criterion of interests of young people. Furthermore, income and family status may have some significance, because economically dependent people may want to save money, and local products are slightly more expensive. In this way, it will be possible to isolate a new group of tourists, and reach them with the promotion of local products on the occasion of various events organised in a given place. As it will be communication targeted at relatively young people, it should be remembered that the textual information should be short and graphic information needs to prevail (Kim et al. 2009).

The proposed concept of cross-promotion does not need to be limited to the Internet materials printed on leaflets, in local press, or available at ticket-selling points can also contain information on local products. Therefore, online information will be available prior to the arrival at a given destination, while the information found at ticket-selling places or on leaflets will be available already at the destination. Both options are equally important, because a tourist purchasing a given product runs a certain risk - appropriate information (promotion) diminishes the potential loss and encourages to buy the products. Therefore, information provided in advance allows, on the one hand, to acquire relevant knowledge, but also to weigh the benefits. 
Contemporary consumers of local and regional products expect benefits just as with any other shopping, so promotional actions have to address this consistently.

It should be noted here that a good promotion of regional products requires self-organisation of producers into groups of collective action, as well as thinking in terms of the region and the local product. Together, it will be easier to disseminate knowledge about these products to potential consumers (Smak i tradycja, 2004). Therefore, it seems that tourism related to local products should not be a single offer, but a network - the offer of local products, their promotion and delivery to the market ought to be a joint venture of entities involved in tourism of a given destination (Sikorska, 2018).

\section{Conclusions}

The first objective of the article was to determine what percentage of visitors to the coastal tourist destinations is interested in local products and what they thought of them. The research shows that $67.3 \%$ of respondents are interested in regional products, and $74 \%$ in this group are willing to buy them. In the respondents' opinion, the main reasons for arousing interest in local products are taste, quality and beneficial effects on health. It is significant that nearly $65 \%$ of respondents interested in local products confirmed that their interest in regional products also translated into a desire to visit the region. This means that these products constitute an important element arousing interest in a tourist destination.

The second objective was to determine the traits of people who were not interested in local products, and to propose a modified segmentation of the market as well as a communication concept. It turns out that those uninterested in local product are young people (19-35) who come to the coastal town mostly for recreational purposes. It is, however, evident that the main criterion distinguishing the surveyed respondents is age, and this perspective should be the starting point in the process of segmentation. Furthermore, tourists should be divided in terms of their interests (music, sport), as well as in terms of family status (single people, families with children). At a later stage, income may be important, because economically dependent people may want to save money, as local products are a bit more expensive. Nonetheless, this approach to segmentation will distinguish two main groups of tourists: 1) interested in local products, and 2) uninterested in local products. Promotion of local products can be addressed to both groups, yet, in the case of the uninterested tourists it should have a form of cross-promotion accompanying various events taking place at a given location. Such an approach will create an opportunity to deliver information on local products on many occasions (e.g. concerts, cabaret performances, sporting events). Activities at the holiday destination should be implemented in parallel with promotion on the Internet, which is a medium used by young people. Thus, the information on the Internet will be available prior to arriving at a given destination, 
while it will also be accessible locally on leaflets or during ticket sales. Such a two-phase crosspromotion concept seems the most efficient.

\section{References}

1. Aprile, M.C., Caputo, V., Nayga, R. Jr. (2016). Consumers' preferences and attitudes toward local food products. Journal of Food Products Marketing, 22(1), 19-42.

2. Barlagne, C., Bazoche, P., Thomas, A., Ozier-Lafontaine, H., Causeret, F., Blazy, J.-M. (2015). Promoting local foods in small island states: The role of information policies. Food Policy, 57, 62-72.

3. Barros, C.P., Botti, L., Peypoch, N., Robinot, E., Solonandrasana, B., Assaf, G. (2011). Performance of French destinations: Tourism attraction perspectives. Tourism Management, 32, 141-146.

4. Bucher, S. (2015). Tourism Competitiveness in European Destinations: Measuring of the Tourism Competitiveness Index. Ekonomicky Casopis, 63(6), 634-655.

5. Castañeda, J.A., Frías, D.M., Rodríguez, M.A. (2009). Antecedents of internet acceptance and use as an information source by tourists. Online Information Review 33(3), 548-567.

6. Dąbrowska, A. (2018). Zachowania konsumentów na rynku żywnościowych produktów tradycyjnych i regionalnych. Wyzwania dla marketingu. Handel Wewnętrzny, 3(374), 106-117.

7. European Commission website, https://europa.eu/european-union/topics/food-safety_en, 13 August 2019.

8. European Commission. Food safety and quality, https://ec.europa.eu/info/food-farmingfisheries/food-safety-and-quality_en.

9. Fields, K. (2002). Demand for the gastronomy tourism product: Motivational factors. In: A.-M. Hjalager, and G. Richards (Eds.), Tourism and gastronomy (pp. 36-50). London: Routledge.

10. Grębowiec, M. (2017). Produkty regionalne i tradycyjne jako element budowania konkurencyjnej oferty produktów. Zeszyty Naukowe Szkoły Głównej Gospodarstwa Wiejskiego w Warszawie Problemy Rolnictwa Światowego, 17(XXXII), 2, 65-80.

11. Gulbicka, B. (2014). Żywność tradycyjna i regionalna $w$ Polsce. Instytut Ekonomiki Rolnictwa i Gospodarki Żywnościowej Państwowy Instytut Badawczy w Warszawie, 13-21.

12. Hernik, J., Smalec, A. (2013). Marketing communication of local government vs. tourists` expectations. Annals of the University of Bucharest, Economic and Administrative Sciences Series, VII, 43-58. 
13. Jung, T.H., Ineson, E.M., Miller, A. (2014). The Slow Food Movement and sustainable tourism development: a case study of Mold, Wales. International Journal of Culture, Tourism and Hospitality Research, 8(4), 432-445.

14. Kim, J., Kim, M., Lennon, S. (2009). Effects of web site atmospherics on consumer responses: music and product presentation. Direct Marketing: An International Journal, 3, 1, 4-19.

15. Kozak, N., Kozak, M. (2008). Information sources available to visitors: a segmentation analysis, Tourism Review, 63, 4, 4-12.

16. Kozioł, L. 2012. Trójczynnikowa koncepcja motywacji turystycznej. Zeszyty Naukowe Uniwersytetu Szczecińskiego, 699, Ekonomiczne Problemy Usług, 84, 43-52.

17. Madaleno, A., Eusébio, C., Varum, C. (2018). Purchase of local food products during trips by international visitors. International of Tourism Research, 20, 115-125.

18. Malkowski, A. (2017). Strategia jako narzędzie zarządzania obszarem przygranicznym na przykładzie wybranych gmin pogranicza zachodniego. Przedsiębiorczość i Zarzadzanie, 18(2/3), 41-56.

19. Marrocu, E., Paci, R. (2011). They arrive with new information. Tourism flows and production efficiency in the European regions. Tourism Management, 32, 750-758.

20. McLoughlin, E., Hanrahan, J. (2019), Local authority sustainable planning for tourism: lessons from Ireland. Tourism Review, 74, 3, 327-348.

21. Michota-Katulska, E., Boniecka, I., Ukleja, A. (2008). Rola żywności tradycyjnej $\mathrm{w}$ rozwoju i promocji turystyki $\mathrm{w}$ regionach. In: Tradycyjne i regionalne technologie i produkty $w$ żywieniu człowieka. Lublin: Uniwersytet Przyrodniczy, 46.

22. Ministry of Agriculture and Rural Development, https://www.gov.pl/web/rolnictwo/ przepisy-polskie-produkty-regionalne-i-tradycyjne, https://www.gov.pl/web/rolnictwo/ produkty-regionalne-i-tradycyjne1, https://www.gov.pl/web/rolnictwo/lista-produktowtradycyjnych12, 17 August 2019.

23. Regulation of the European Parliament and of the EU Council No. 1151/2012 of 21 November 2012 on quality systems for agricultural products and foodstuffs.

24. Rodríguez del Bosque, I., San Martín, H., Collado, J., García de losSalmones, M. (2009). A framework for tourist expectations. International Journal of Culture, Tourism and Hospitality Research, 3, 2, 139-147.

25. Sikorska, M. (2018). Wiejskie siedliska, czyli o tym czego pragną... turyści? Biokurier.pl as of 9 November 2018. Available online: https://biokurier.pl/relaks/eko-turystyka/czegopragna-turysci/.

26. Smak i tradycja (2004). Biuletyn informacyjny Polskiej Izby Produktu Regionalnego, 1, 5, https://ec.europa.eu/agriculture/quality/door/list.html?locale=pl, 17 August 2019.

27. Suhartanto, D., Chen, B., Mohi, Z., Sosianika, A. (2018), Exploring loyalty to specialty foods among tourists and residents. British Food Journal, 120, 5, 1120-1131. 
28. Woźniczko, M. (2015). Stan rynku żywności regionalnej i tradycyjnej w Polsce. Postępy techniki przetwórstwa spożywczego, 1 .

29. WTO, Press Release from 18 June 2019. Tourism: A Global Force For Growth And Development - UNWTO Executive Council meets in Baku, http://www2.unwto.org/pressrelease/2019-06-18/tourism-global-force-growth-and-development-unwto-executivecouncil-meets-b.

30. Wu, S., Fooks, J.R, Messer, K.D., Delaney, D. (2015). Consumer demand for local honey. Applied Economics, 47(41), 4377-4394. 